UDC 658.3.07

\author{
V. KYRIY, O. LIUBICHEVA, K. MOSKAVTSOVA
}

\title{
STRATEGY OF HR DEVELOPMENT AT HIGH-TECH ENTERPRISES
}

The subject matter of the study is the mechanism of functioning and development of HR high-tech enterprise. In Ukraine, the most high-tech sector of the economy is represented by the information technology sector, namely the sub-sector of the development and implementation of information products and services. The relevance of researching HR processes in high-tech enterprises is due not only to the rapid growth of the IT sector of the Ukrainian market, but also to the need to study the work of the HR system taking into account the stages of the life cycle of such an enterprise. The development of a high-tech sector requires the continuous development of HR methods and tools. The goal of the work is to study the current state and directions of HR development in IT enterprises in accordance with the stages of the life cycle of such enterprises. The objectives of the work are to summarize the existing practical trends in HR and to study their structural characteristics; to improve the criterial approach to determining the relationship between the stage of the life cycle of a high-tech enterprise and the stage of development of the HR service. The general scientific and applied methods of theoretical and empirical research were used in the work: observation, comparison and analysis of empirical data, generalization, synthesis - for posing a problem, studying the laws of the development of the object of research; statistical - to assess the current state of the industry; graphic - to illustrate the results of the activities of enterprises and the formulation of findings of the studies. The result of the research is the formation of the fundamentals of a criterial approach to determining the relationship between the stage of the life cycle of a high-tech enterprise and the stage of development of the HR based on the ordering of existing trends in the field of HR. It is determined that strategic direction for modern enterprises is creation of HR-business partner, which will allow to solve complex problems of modern adaptive HR management tasks. The proposed indicators of HR performance evaluation depending on the stage of HR development.

Keywords: HR high-tech enterprises, evaluation of activity HR, stages of HR development, strategy of development HR.

\section{Introduction}

In Ukraine, the IT sector is growing by almost $25 \%$ each year, and it has grown cumulatively by 10 times in the last ten years [1]. Such rate of growth determines the high level of competitiveness of high-tech enterprises. Along with the accumulation of financial resources, the feature of the manufacturing process at such enterprises is producing information and intellectual product, which sets the priority of human resources at IT-enterprises. Together with the growth of the market, an increase in the number of trained specialists, qualified professionals are increasingly required in the IT sphere. That is why competent human resources policy is a guarantee of the successful operation and high level of competitiveness of a high-tech IT enterprise.

The staff policy, in this case, is considered as the systematic managing the personnel of an enterprise by determining goals and methods for achieving them [2]. The urgency of the theoretical generalization and research of HR-processes at high-tech enterprises is caused by the rapid growth of the IT sector of the Ukrainian market, the need to study the HR system in terms of the life cycle stages of such an enterprise. The development of the hightech sector requires adapting HR methods and tools. The automation of HR processes is becoming more and more widespread [3], and at this stage of development, HR acquires the features of both management and service.

\section{The analysis of literary sources and problem statement}

HR is a structural subdivision of an enterprise business line which systematically executes the function of personnel management of the enterprise. HR activities are diverse and multifunctional and are involved in all areas of the activities of the enterprise. Constant exaggerated development of the high technology field specifies the permanent adaptation of HR service. The main trends of HR operation at a high-tech enterprise are given in fig. 1:

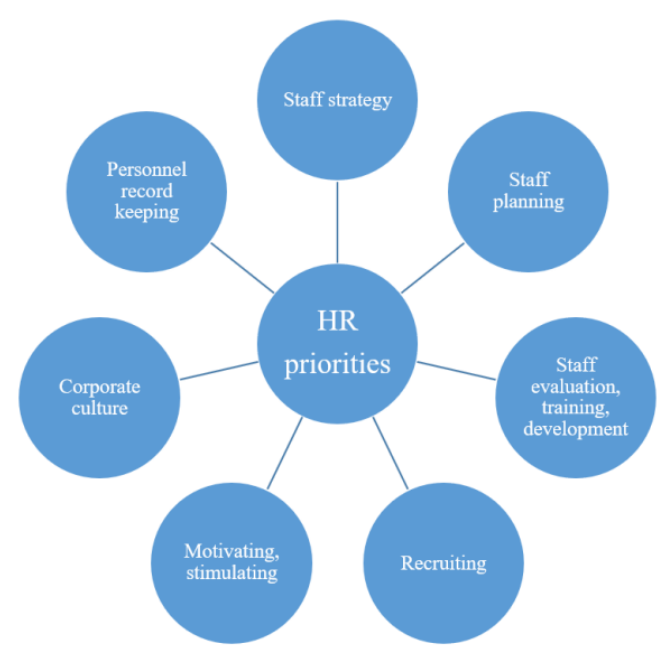

Fig. 1. The main trends of HR operation (author's development based on) [2] 
Each HR trend presented in Fig. 1 includes a number of tasks related to managing human resources. The urgent task of an HR-specialist is not only to hire an employee, thus filling the vacancy, but also to ensure its integration into the team, help realize professional skills and personal qualities, give an opportunity to improve qualifications and, finally, create a team of creators. Let us consider the tasks within the HR system for each trend (table 1).

Table1. The characteristics of HR trends

\begin{tabular}{|c|c|}
\hline Trend & Tasks within the trend \\
\hline Staff strategy & $\begin{array}{l}\text { determining the objectives of the staff policy in accordance with the strategic objectives of an } \\
\text { enterprise; } \\
\text { human resources management within the framework of the objectives of staff policy }\end{array}$ \\
\hline Staff planning & determining future quantity and quality of employees \\
\hline $\begin{array}{l}\text { Staff evaluation, } \\
\text { training, development }\end{array}$ & $\begin{array}{l}\text { conducting preliminary training; } \\
\text { staff training; } \\
\text { additional advanced training for prospective employees; } \\
\text { recruitment }\end{array}$ \\
\hline Recruiting & recruitment \\
\hline Motivating, stimulating & $\begin{array}{l}\text { selecting the methods of motivation; } \\
\text { conducting incentive measures }\end{array}$ \\
\hline Corporate culture & $\begin{array}{l}\text { familiarizing new employees with corporate culture; } \\
\text { integrating new employees into the company system; } \\
\text { supporting corporate culture; } \\
\text { holding events within the enterprise; } \\
\text { assigning company goals to the goals of employees within the corporate management }\end{array}$ \\
\hline $\begin{array}{l}\text { Staff records } \\
\text { management and staff } \\
\text { accounting }\end{array}$ & $\begin{array}{l}\text { timekeeping; } \\
\text { distribution of employment; } \\
\text { developing the mechanism of monetary reward for the work done }\end{array}$ \\
\hline
\end{tabular}

Modern trends of HR development within each trend enable distinguishing several essential features. Due to the high growth rates of demand for IT professionals, time for executing HR tasks is reduced and therefore they require automation. There is a large increase in a number of software developed for HR automation which gradually transforms all processes of interaction with employees into a completely new approach [4]. This trend affects the principles of recruitment as at present efficient employment is similar to the talent management.

The next major trend is the transformation of organizational culture. These are qualitative changes that lead to cross-functional interaction at enterprises of any size. HR becomes a separate brand which is targeted by specialists and this brand in view of dominating the service model of the IT business in Ukraine is a competitive advantage of the company [3].

The goal and objectives of the study are to study the current state and trends of HR development at hightech enterprises according to the stages of the life cycle of such enterprises. The object of the research is the process of HR operation at a high-tech enterprise. The subject of the research is the principles and mechanism of the operation and development of HR high-tech enterprise.

\section{Materials and methods of the study}

In the course of researching general scientific and applied methods of economic analysis were used observation, the comparison and analysis of empirical data - for problem statement, studying the laws of development of the object of research; statistical - for assessing the current state of the industry; graphical - for illustrating the results of enterprise activities and drawing conclusions of the research.
The works of Ukrainian and foreign scholars have become the informational and theoretical basis of the study.

\section{The results of the study}

Any development is characterized by a number of factors which, in turn, determine the development of both the whole system and its separate subsystems, structural and functional connections. Therefore, determining the structure of connections, the signs and factors that characterize the relationship between HR development and the life cycle stages of high-tech IT enterprise are of great interest.

Let us determine the level of HR development as the stage of management of the staff subsystem at an enterprise which corresponds to certain areas of work and life cycle of the enterprise itself. Basing on the operation of the subsystem of personnel management during the transition from the operational function to the implementation of strategic business tasks, the following levels of HR development at the enterprise should be highlighted:

- workforce management: at this level of development, at the enterprise, there is an office manager or recruiter whose responsibilities include recruitment, personnel management;

- staff management: there is an HR department which becomes responsible for optimizing a number of employees, maintains statistical records and basic HR communications with other enterprise systems;

- human resource management: at this level HR becomes a business partner, therefore, the employment and development of human resources of the enterprise is characteristic for this level [5]. 
The reasons for this division result from the goal of the study, that is to analyze and determine the relationship between the stages of HR development and the stages of the life cycle of the enterprise. In general, it should be noted that some researchers determine different stages in the development of the human resources management system, others assign them to the stages of the life cycle of the organization or company [6], still others characterize them separately [7]. Investigating factors that determine the level of HR development also points to their wide variety. I. Voronkov points to factors that characterize the level of development of the company - a number of employees, access to capital and determining objectives [6]; others point to the following factors - the level of perception of HR functions by top management, teamwork skills, professionalism. K. Osadchuk, who is the well-known professional in this area, points to the factors that determine HR as the stage of business development, the maturity of management and the maturity of HR itself [8].

Summarizing the work of researchers, it can be pointed out that the above factors do not fully reflect the relationship between the level of HR development and its determinants for IT enterprises being considered. The correspondence of the suggested HR development levels at the enterprise and a set of determinants is presented in table 2 .

Table 2. The ratio of the level of HR development and its determinants

\begin{tabular}{|l|c|c|c|}
\hline \multirow{2}{*}{ Factor } & \multicolumn{2}{|c|}{ HR development level } \\
\cline { 2 - 4 } & Workforce management & Staff management & HR management \\
\hline $\begin{array}{l}\text { Company goals and } \\
\text { asks }\end{array}$ & Extensive development & $\begin{array}{c}\text { Extensive development } \\
\text { Intensive development } \\
\text { Maintaining the achieved position } \\
\text { Reducing enterprise size }\end{array}$ & $\begin{array}{c}\text { Intensive development } \\
\text { Maintaining the achieved position } \\
\text { Reducing the size of an enterprise }\end{array}$ \\
\hline Enterprise size & small & medium, large & medium, large \\
\hline $\begin{array}{l}\text { The stage of company } \\
\text { development }\end{array}$ & $\begin{array}{c}\text { Development based on } \\
\text { creativity }\end{array}$ & $\begin{array}{c}\text { Development based on guidance } \\
\text { Development based on delegation } \\
\text { coordination }\end{array}$ & Development based on cooperation \\
\hline $\begin{array}{l}\text { Organizational } \\
\text { structure }\end{array}$ & hierarchical & functional & functional \\
\hline $\begin{array}{l}\text { The level of HR- } \\
\text { tasks complexity }\end{array}$ & monofunctional & multifunctional & multifunctional \\
\hline
\end{tabular}

The main factors are the business model, the size of the enterprise and the stage of its development as, due to their objectivity and validity, they are not affected by various external and internal factors in the short run. All other factors are subjective and can change at any stage of the life cycle of the enterprise in a rather short time.

Let us consider the strategy of development and trends of HR activities in interaction with the stages of development of hi-tech enterprises that are based on the Greiner model [9] which describes the stages of development of the IT enterprise in a sufficient way. This model consists of five stages of development and the transitions among them or crises. They can become both an impact for further development and a reason for the business cessation [10].

The connection among the enterprise life cycle (ELS), HR development stage and its main trends are shown in table 3 .

The distribution of $\mathrm{HR}$ responsibilities and authorities is presented in fig 2.

Top management of modern high-tech enterprises indicates that the HR-business partner helps provide leaving the regression stage since it enables distributing risks among all participants within the production process of the company. Therefore, any company should pursue catching up with this level of HR development. Let us detail the task of HR-business partner:

Table 3. The stages of the enterprise life cycles, HR development stage, and HR main trends

\begin{tabular}{|c|c|c|c|c|c|}
\hline ELS stage & $\begin{array}{c}\text { Development } \\
\text { based on } \\
\text { creativity }\end{array}$ & $\begin{array}{l}\text { Development } \\
\text { based on } \\
\text { guidance }\end{array}$ & $\begin{array}{c}\text { Development } \\
\text { based on } \\
\text { delegation }\end{array}$ & $\begin{array}{c}\text { Development based } \\
\text { on coordination }\end{array}$ & $\begin{array}{l}\text { Development based on } \\
\text { cooperation }\end{array}$ \\
\hline $\begin{array}{c}\text { HR } \\
\text { development } \\
\text { stage }\end{array}$ & $\begin{array}{l}\text { Workforce } \\
\text { management }\end{array}$ & \multicolumn{2}{|c|}{ Staff management } & \multicolumn{2}{|c|}{ HR management (the level of a business partner) } \\
\hline $\begin{array}{l}\text { Main trends of } \\
\text { operation }\end{array}$ & $\begin{array}{l}\text { Recruiting } \\
\text { Staff records } \\
\text { management } \\
\text { Staff } \\
\text { accounting }\end{array}$ & \multicolumn{2}{|c|}{$\begin{array}{l}\text { Recruiting } \\
\text { Staff records management } \\
\text { Staff accounting } \\
\text { Staff strategy } \\
\text { Corporate culture development } \\
\text { Staff planning } \\
\text { Staff motivating and stimulating }\end{array}$} & $\begin{array}{l}\text { Staff records } \\
\text { management } \\
\text { Staff accounting } \\
\text { Corporate culture } \\
\text { support } \\
\text { Staff strategy } \\
\text { implementation } \\
\text { Staff evaluation, } \\
\text { training, developmen }\end{array}$ & $\begin{array}{l}\text { Staff accounting } \\
\text { Corporate culture } \\
\text { support Staff strategy } \\
\text { implementation }\end{array}$ \\
\hline
\end{tabular}




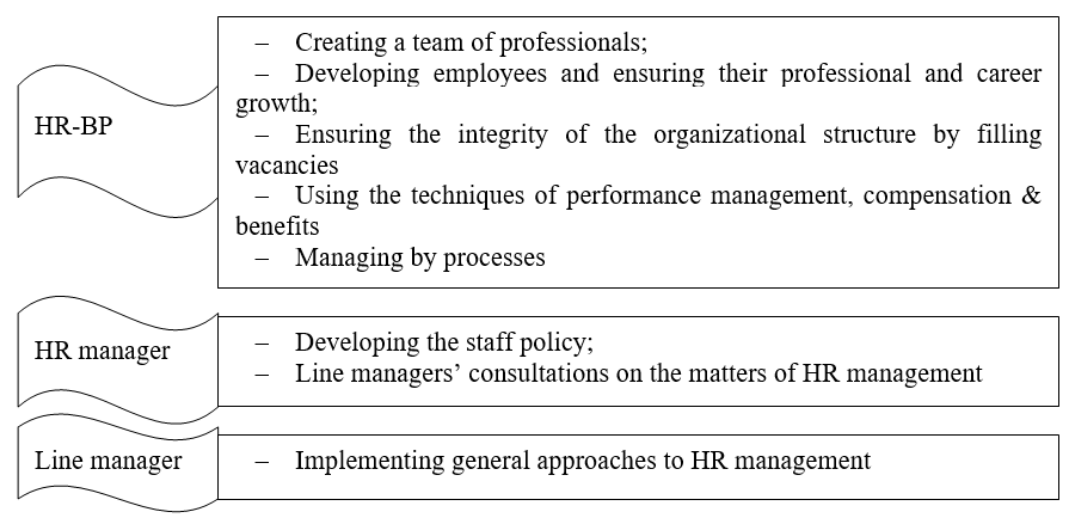

Fig. 2. Distribution of HR responsibilities and authorities

1. Creating a team of professionals.

This is the primary link of the HR of a new generation where some HR workers acquire some elements of a business partner while they are basically performing the target task. At high-tech enterprises with a large number of creative workers, this aspect of HR work is very important as, in many cases, teamwork on longterm projects is required. The business partner provides integration of old and new employees, helps in solving probable conflicts among them.

2. Developing employees and ensuring their professional and career growth.

HR-business partner permanently guides the increase of professional skills of the personnel. The creativity of the workers in the area is mostly supported and guided by their aspirations for development but the shortage of own resources (financial, temporal) reduces the activity of this direction. The task of HR is to identify prospective employees, provide them with the opportunity to study and develop, and monitor this process. The logical completion and further continuation of training is the career advancement of successful employees, the preparation of own personnel.

3. Ensuring the integrity of the organizational structure by filling vacancies.

At any stage of the company life cycle, it is critical that the organizational structure of the enterprise matches its goals. The task of HR is to participate in the approval of the final version of the organizational structure of a high-tech enterprise and to redistribute human resources in the most optimal way.

4. Using the techniques of performance management, compensation $\&$ benefits.

Performance management is, first of all, a mechanism of the remuneration for the work done as well as for the management of all resources of the enterprise including human resources that are aimed at effective interaction, the main principle of which is achieving the necessary result by developing the skills of employees, in particular, the ability to work in a team and by offering the corresponding remuneration.

Compensation \& benefits are the HR technique which comprises both tangible (financial) and nontangible methods of remuneration (professional recognition and development) [11]. The efficiency of these techniques entirely depends on the processes of analysis, planning and predicting that are carried out by HR-businesspartner. The conditions inside the company and in companies-competitors as well as in the labour market in the corresponding segment should be analyzed.

5 . Managing by processes.

The process approach should become the basis and ground for determining the tasks of each structural unit of the company in a transparent way, which allows HR to monitor their tasks and processes, to know the processes of each employee and observe them.

HR-business-partner should be supported by techniques. Most high-tech enterprises use automated solutions for staff records management and calculation of salary and the automation of other HR-processes (recruitment, adaptation in the workplace, assessment, development, training, retention) is gathering speed. The automation of HR helps bring it to a new level of development in the context of the company growth as well as facilitate the execution of routine tasks. Recruiters actively begin to use HR-bots, i.e. a special kind of chatbots that perform a number of specific functions to automate the HR service partially [3]. The functions of HR-bots include:

- the interaction with applicants (quick response to applications, information about the company and requirements, feedback after testing);

- processing test results of applicants (analysis of test results);

- providing informing about vacancies or opportunities for career advancement (information distribution among applicants who have left their coordinates for employees).

Due to the fact that these bots are used to automate HR tasks, they have some advantages:

- the high speed of selecting candidates (several tens of times higher than when interviews or tests are conducted by a regular specialist);

- minimal costs (costs are much lower than the costs for a number of specialists who would perform the same amount of work within the same time).

Such bots also have disadvantages:

- the lack of personal evaluation;

- the impossibility to apply the knowledge and experience of a recruiter.

Despite the fact that the automation of HR tasks gives many advantages, chatbots are not able to replace the experts completely. In HR, a human factor has a large share and this allows HR-bots to replace specialists only in some tasks and, as a rule, only at the initial stages. Also, at this stage of development, a significant place is 
occupied by talent management systems in the automation of HR. Such programmes help automate the management of employee training, monitoring learning outcomes, bonus calculation, and so on.

It is important not only to identify the stage of the HR development but also to monitor its activities. Economic science has developed a large number of criteria that determine the quality of HR work. It is convenient to evaluate HR using not individual criteria but their groups. These groups of criteria reflect the use of employees' skills, abilities and personal qualities for performing official duties and solving professional tasks. The criteria are divided into three groups:

1. Corporate criteria that are basic competence not only for HR but also for any employee whose competence is related to the key characteristics of the company and its values. They include focusing on the outcome, high professionalism, initiative, teamwork, business aggressiveness, loyalty and motivation to train and learn.

2. Professional criteria for HR that include gathering information on the state of the market, its analysis, predicting; planning the solution of tasks within different HR trends; making professional decisions.

3. Real results. This group of criteria covers a wide range of different indicators of HR efficiency depending on the activity.

The evaluation of HR activities for an IT enterprise has a number of features related to the specificity of the industry that also dictates the need for careful selection of the indicators of HR efficiency. This process takes place at several stages:

1. Determining the goal of the evaluation of $\mathrm{HR}$ activities. include:

There are many goals for evaluating HR. They

- selecting the tactics of HR development (in the context of temporary changes in the staff policy or when the changes in HR policy is necessary in the short run);

- selecting the strategy for HR development (changes in the long run, if necessary);

- general monitoring (evaluation of HR at the current moment);

- analyzing the activities of all departments of the enterprise;

- anti-crisis analysis;

- analysis during the reorganization / restructuring of the enterprise.

There are several approaches to determining the stage of an enterprise development. The main one is the quantitative and qualitative approach. The quantitative approach lies in the dynamic evaluation of the enterprise performance. This dynamics is associated with the stage of development of a high-tech enterprise. When applying the qualitative approach, the current state of the enterprise is compared to different stages of the enterprise development on the qualitative level and the appropriate one is selected. However, using the mixed approach is the most reliable. Quantitative indicators can grow due to external changes, for example, the expansion of the market at the expense of new consumers. Qualitative changes in this aspect are more reliable, but they do not have the quantitative reinforcement unless a mixed approach is used. This approach can reliably determine the stage of development of a high-tech enterprise. The following stages are distinguished (according to the Greiner model):

- development based on creativity;

- development based on guidance;

- development based on delegation;

- development based on coordination;

- development based on cooperation.

3. Selecting corresponding indicators for evaluating HR operation.

When selecting the indicators for evaluating HR operation, it is appropriate to use three groups of criteria. When evaluating the indicators of all three groups of criteria, the analysis is the most effective.

4. Calculating the selected indicators.

The indicators can be calculated both at a certain moment of time and for any period. It is recommended to calculate the indicators over time periods as during the analysis the obtained results can be compared with the results obtained within past periods and consider the factors that affected these results.

5. Analyzing the results obtained.

The obtained results can be analyzed both by top managers and HR-managers. The responsibilities of HRbusiness partner include evaluating the HR activities and analyzing the results.

6. Applying the analysis of the research.

This stage is final; it is the most important one in the process of evaluating HR activities. According to the obtained results and their analysis, the management makes decisions in accordance with the purpose of evaluating HR activities, which initially had to be supported by the results of this evaluation.

In its general view, the process of evaluation of the HR activities at an IT-enterprise is shown in fig. 3 .

The evaluation of HR activities at an IT enterprise has a number of features related to the specifics of the industry and also the stage of development of the enterprise.

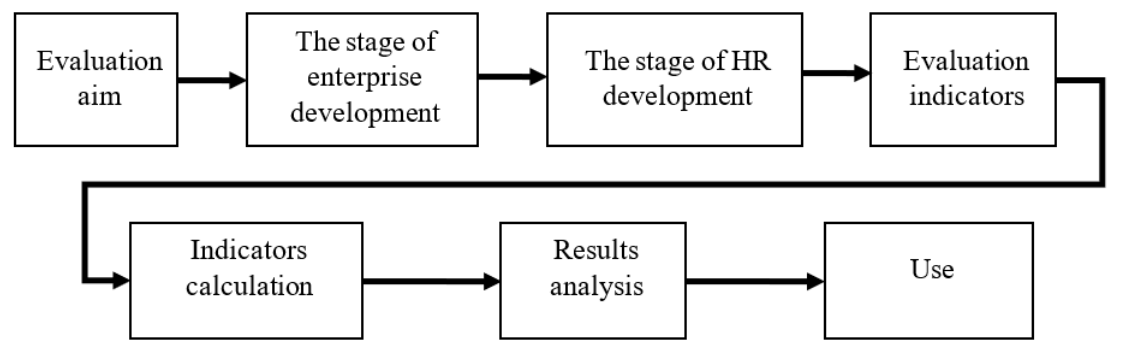

Fig. 3. The process of evaluating the HR activities at a high-tech enterprise 
The indicators of HR efficiency in the IT sphere should be comprehensive taking into account the high level of technology of the industry. The processes and trends of HR-services operation change at different stages of the life cycle of the enterprise. Therefore, it is inefficient to evaluate HR activity using the same indicators constantly. They can be tracked for each individual employee, for each trend of operational and throughout the whole department or direction. Primary indicators are presented in table 4.

Table 4. The indicators of the efficiency evaluation of the HR-system activities at a high-tech enterprise

\begin{tabular}{|l|l|}
\hline \multicolumn{1}{|c|}{ The stage of high-tech enterprise development } & \multicolumn{1}{|c|}{ Indicators of the efficiency evaluation of the HR-system activities } \\
\hline Development based on creativity & $\begin{array}{l}\text { The rate of vacancies filling } \\
\text { Executing the recruitment plan }\end{array}$ \\
\hline Development based on guidance & $\begin{array}{l}\text { The percentage of employees who underwent a probation period } \\
\text { Executing the recruitment plan } \\
\text { The total idle time of vacancies }\end{array}$ \\
\hline Development based on delegation & $\begin{array}{l}\text { The average length of employment } \\
\text { The percentage of applicants from companies-competitors }\end{array}$ \\
\hline Development based on coordination & Subjective evaluation of top and middle-management \\
\hline Development based on cooperation & A number of recruitment methods \\
\hline
\end{tabular}

\section{Conclusions}

The staff policy of a high-tech enterprise determines the trend of its development and the level of competitiveness. The work deals with the current state and HR trends in high-tech enterprises, the ratio of the level of HR development and the life cycle stage of such an enterprise, the process of evaluation of HR-service activity. As a result, the available practical HR trends were summarized.

There is a close connection between the stage of the life cycle of a high-tech enterprise and the level of HR development at this enterprise. The criterial approach to determining the connection between the stage of the life cycle of a high-tech enterprise and the stage of HR service development is improved. The level of development is determined by a set of factors; the main ones are the business model, the size of the enterprise and the stage of its development. The most important factor for the enterprise is the level of HR-business-partner.

This level should be supported up by techniques. The automation of HR helps bring it to a new level of development with the corresponding growth of the company as well as facilitate the execution of routine tasks.

Evaluating the HR activities at a high-tech enterprise is an integral part of its business processes. Depending on the stage of development of the enterprise and the level of HR development, different indicators for the evaluation can be selected. The analysis of the results and their application enables making the strategy of HR development at a high-tech enterprise flexible, which allows the company to adapt to internal and external changes fast.

\section{References}

1. Labor market 2017: $27 \%$ growth, deficit of IT specialists, relocation of lords [Rynok truda 2017: rost 27\%, defitsit ITspetsialistov, relokatsiya sen'orov]. Available at : https://dou.ua/lenta/articles/jobs-and-trends-2017/?from=doufp.

2. Yevtushenko, V. A, Posilkina, O. V., Egorova, O. Yu. (2003), Labor Economics: Textbook [Ekonomika pratsi: navchal $\square$ nyy posibnyk]. Kharkiv: Golden Pages. 208 p.

3. The Seven Major HR Trends of 2017 [Sem' glavnykh HR-trendov 2017 goda]. Conference "HeadHunter". Available at: https://hh.ru/article/505218.

4. L'vova, A. Technological HR or Perfect HR? [Tekhnologichnyy HR ili Ideal'nyy HR?]. Available at: http://hbrrussia.ru/upload/iblock/1c8/1c8e89416c057fa41a54b0546cb09428.pdf.

5. Mostovaya, Ye. V. (2016), HR-Generalist: a textbook. Kharkiv.

6. Stages of HR department development [Etapy razvitiya HR-podrazdeleniya]. Available at : http://www.ht.ru/cms/component/content/article/1-aricles/101408--hr-hr-

7. Business and HR: development trends [Biznes $\mathrm{i}$ HR: tendentsii razvitiya]. Available at: $\mathrm{http}: / /$ mainjob.ru/publications/?view=6678.

8. HR in IT: from beginner to business partner [HR $\mathrm{v}$ IT: ot novichka do biznes-partnera]. DOU. Available at: https://dou.ua/lenta/columns/hr-br-in-it/.

9. Greiner, L. (1972), "Evolution and revolution as organizations grow". Harvard Business Review. Vol. 50. No. 4. P. $37-46$.

10. Kiriy, V. V., Lyubicheva, O. I., Moskavtsova, Ye. O. (2017), "Research of factors of competitiveness of the hi-tech enterprises in dynamics of stages of a life cycle" ["Issledovaniye faktorov konkurentosposobnosti vysokotekhnologichnykh predpriyatiy $\mathrm{v}$ dinamike etapov zhiznennogo tsikla"]. Biznesinform. No. 5. C. 172-178.

11. Zaffron, L., Steve, D. (2009), Performance Management: The Three Laws of Performance: Rewriting the Future of Your Organization and Your Life. John Wiley \& Sons. 256 p.

Received 11.10.17

Відомості про авторів / Сведения об авторах / About the Authors

Кирій Валентина Василівна - кандидат економічних наук, доцент, Харківський національний університет радіоелектроніки, доцент кафедри економічної кібернетики та управління економічною безпекою, м. Харків, Україна; е-таil: valentyna.kyriy@nure.ua; ORCID: 0000-0002-2537-264X.

Кирий Валентина Васильевна - кандидат экономических наук, доцент, Харьковский национальный университет радиоэлектроники, доцент кафедры экономической кибернетики и управления экономической безопасностью, г. Харьков, Украина; e-mail: valentyna.kyriy@nure.ua; ORCID: 0000-0002-2537-264X. 
Kyriy Valentyna - PhD (Economics), Associate Professor, Kharkiv National University of Radioelectronics, Associate Professor of the Department of Economic Cybernetics and Management of Economic Security, Kharkiv, Ukraine; e-mail: valentyna.kyriy@nure.ua; ORCID: 0000-0002-2537-264X.

Любічева Ольга Ігорівна - Харківський національний університет радіоелектроніки, студентка кафедри економічної кібернетики та управління економічною безпекою, м. Харків, Україна; e-mail: olha.liubicheva@nure.ua; ORCID: 0000-0002-7250-2929.

Любичева Ольга Игоревна - Харьковский национальный университет радиоэлектроники, студентка кафедры экономической кибернетики и управления экономической безопасностью, г. Харьков, Украина; e-mail: olha.liubicheva@nure.ua; ORCID: 0000-0002-7250-2929.

Liubicheva Olga - Kharkiv National University of Radioelectronics, Student of the Department of Economic Cybernetics and Management of Economic Security, Kharkiv, Ukraine; e-mail: olha.liubicheva@ nure.ua; ORCID: 0000-0002-7250-2929.

Москавцова Катерина Олегівна - Харківський національний університет радіоелектроніки, студентка студентка кафедри економічної кібернетики та управління економічною безпекою, м. Харків, Україна; e-mail: moskavkate@gmail.com; ORCID: 0000-0002-1980-9200.

Москавцова Екатерина Олеговна - Харьковский национальный университет радиоэлектроники, студентка кафедры экономической кибернетики и управления экономической безопасностью, г. Харьков, Украина; e-mail: moskavkate@gmail.com; ORCID: 0000-0002-1980-9200.

Moskavtsova Kateryna - Kharkiv National University of Radioelectronics, Student of the Department of Economic Cybernetics and Management of Economic Security, Kharkiv, Ukraine; e-mail: moskavkate@gmail.com; ORCID: 0000-0002-1980-9200.

\section{СТРАТЕГІЯ РОЗВИТКУ НR НА ВИСОКОТЕХНОЛОГІЧНИХ ПІДПРИЕМСТВАМ}

Предметом дослідження $є$ механізм функціонування та розвиток HR високотехнологічного підприємства. В Україні в найбільшій мірі високотехнологічний сектор економіки представлений сектором інформаційних технологій, а саме підгалуззю розробки та впровадження інформаційних продуктів та сервісу. Актуальність дослідження HR-процесів на високотехнологічних підприємствах зумовлена не лише швидкими темпами зростання IT-сектору українського ринку, але й також необхідністю дослідження роботи системи HR з огляду на етапи життєвого циклу такого підприємства. Зростання високотехнологічного сектору потребує невпинного розвитку методів та засобів роботи HR. Метою роботи є дослідження сучасного стану та напрямів розвитку HR на IT підприємствах у співвідношенні до етапів життєвого циклу таких підприємств. Завдання роботи - узагальнення існуючих практичних трендів у сфері HR та дослідження їх структурних характеристик; вдосконалення критеріального підходу до визначення зв'язку між етапом життєвого циклу високотехнологічного підприємства та стадією розвитку HR-служби. У роботі були використані загальнонаукові й прикладні методи теоретичного та емпіричного дослідження: спостереження, порівняння та аналізу емпіричних даних, узагальнення, синтезу - для постановки проблеми, вивчення закономірностей розвитку об'єкта дослідження; статистичні - для оцінки сучасного стану галузі; графічні - для ілюстрації результатів діяльності підприємств і оформлення висновків проведених досліджень. Результатом дослідження є формування основ критеріального підходу до визначення зв'язку між етапом життєвого циклу високотехнологічного підприємства та стадією розвитку HR на основі впорядкування існуючих трендів у сфері HR. Визначено, що стратегічним напрямом для сучасних підприємств є створення HR-бізнес-партнера, що дозволить комплексно вирішувати сучасні задачі адаптивного управління HR. Запропоновані показники оцінки ефективності діяльності HR в залежності від стадії розвитку HR. HR.

Ключові слова: HR високотехнологічних підприємств, оцінка діяльності HR, етапи розвитку HR, стратегія розвитку

\section{СТРАТЕГИЯ РАЗВИТИЯ НR НА ВЫСОКОТЕХНОЛОГИЧЕСКИХ ПРЕДПРИЯТИЯХ}

Предметом исследования являются механизм функционирования и развитие HR высокотехнологичного предприятия. В Украине в наибольшей степени высокотехнологичный сектор экономики представлен сектором информационных технологий, а именно подотраслью разработки и внедрения информационных продуктов и сервиса. Актуальность исследования HR-процессов на высокотехнологичных предприятиях обусловлена не только быстрыми темпами роста ITсектора украинского рынка, но также необходимостью исследования работы системы HR учитывая этапы жизненного цикла такого предприятия. Рост высокотехнологичного сектора требует непрерывного развития методов и средств работы HR. Целью работы является исследование современного состояния и направлений развития HR на ИТ предприятиях в соответствии с этапами жизненного цикла таких предприятий. Задачи работы - обобщение существующих практических трендов в сфере HR и исследование их структурных характеристик; усовершенствование критериального подхода к определению связи между этапом жизненного цикла высокотехнологичного предприятия и стадией развития HR-службы. B работе были использованы общенаучные и прикладные методы теоретического и эмпирического исследования: наблюдение, сравнение и анализ эмпирических данных, обобщение, синтез - для постановки проблемы, изучения закономерностей развития объекта исследования; статистические - для оценки современного состояния отрасли; графические - для иллюстрации результатов деятельности предприятий и оформления выводов проведенных исследований. Результатом исследования является формирование основ критериального подхода к определению связи между этапом жизненного цикла высокотехнологичного предприятия и стадией развития HR на основе упорядочения существующих трендов в сфере HR. Определено, что стратегическим направлением для современных предприятий является создание HR-бизнес-партнера, что позволит комплексно решать современные задачи адаптивного управления HR. Предложены показатели оценки эффективности деятельности HR в зависимости от стадии развития HR.

Ключевые слова: HR высокотехнологичных предприятий, оценка деятельности HR, этапы развития HR, стратегия развития $\mathrm{HR}$ 